\title{
PENGARUH BUDAYA ORGANISASI TERHADAP KINERJA GURU PADA PERGURUAN BUDDHIST MANJUSRI PEMATANGSIANTAR
}

\author{
Oleh: \\ Selvia Yenni Intan \\ S1 Manajemen \\ Darwin Lie, Marisi Butarbutar, Efendi
}

\begin{abstract}
Abstraksi
Adapun rumusan masalah dalam penelitian ini adalah bagaimana pengaruh budaya organisasi terhadap kinerja guru pada Perguruan Buddhist Manjusri Pematangsiantar. Penulis menggunakan desain penelitian yaitu penelitian lapangan dan penelitian kepustakaan. Populasinya adalah guru Perguruan Buddhist Manjusri Pematangsiantar dengan jumlah 40 orang. Metode pengumpulan data adalah melalui wawancara, dokumentasi dan kuesioner yang bersumber dari data primer dan sekunder yang dianalisa dengan analisa deskriptif kualitatif dan analisa deskriptif kuantitatif.

Dari hasil analisa regresi sederhana diketahui bahwa $=14,95+0,595 \mathrm{X}$. Kekuatan hubungan $\mathrm{r}=0,5726$, Kemudian koefisien determinasi $\mathrm{R}=32,78 \%$. Kesimpulan dari penelitian ini adalah budaya organisasi berpengaruh positif terhadap kinerja guru pada Perguruan Buddhist Manjusri Pematangsiantar. Hal ini dapat dilihat dari hasil uji thit $=4,305>\mathrm{ttab}=2,024$. Adapun saran dari penelitian ini adalah perlunya peningkatan pelatihan-pelatihan dan pemberian motivasi terhadap semua tenaga pendidik dan peserta didik dan kemampuan menggunakan in focus, laptop dan internet perlu ditingkatkan.
\end{abstract}

Kata kunci: Budaya Organisasi dan Kinerja Guru

\section{Abstraction}

As for internal issue formula this research is how organizational cultural influence to performance learn at Teacher of Buddhist Manjusri Pematangsiantar. Writer use the design research that is research of field and bibliography research. Its population is teacher of Teacher of Buddhist Manjusri Pematangsiantar with the amount 40 people. Method of data collecting is through interview, documentation and questionnaire from data of primary and secondary analysis with the descriptive analysis qualitative and descriptive analysis is quantitative.

Than result analyze the regression is modestly known that $=14,95+0,595 X$. Strength of Relation $r=$ 0,5726 , Then coefficient of determination $R=32,78 \%$. Conclusion from this research is organizational culture have an effect on positive to performance learn at Teacher of Buddhist Manjusri Pematangsiantar. This Matter is visible from result test the thit $=4,305>\mathrm{ttab}=2,024$. As for suggestion from this research is the importance of make-up of training and gift motivate to all energy of educator and competitor educated and ability use the in focus, laptop and internet require to be improved.

\section{Keyword: Organizational Cultural and Teacher Performance}

\section{A. PENDAhuluan}

\section{Latar Belakang Masalah}

Fenomena kinerja guru yang terjadi di Perguruan Buddhist Manjusri Pematangsiantar belum optimal. Dimana fenomena kinerja guru untuk tahun ajaran 2012/2013 ini didapatkan dari hasil wawancara. Fenomena ini dapat dilihat dari tabel diberikut ini: Sebanyak $70 \%$ guru mengajar hanya dengan menggunakan buku paket yang menjadi buku pegangan mereka dan belum adanya proses belajar mengajar menggunakan media seperti: in focus, laptop dan internet. Sebanyak $80 \%$ guru masih belum bisa menciptakan suasana belajar yang sehat dimana faktanya masih terdapat murid yang sering permisi dan berada di luar kelas selama proses jam belajar mengajar. Sebanyak $65 \%$ guru tidak menilai prestasi murid untuk kepentingan pengajaran tetapi guru hanya menilai proses belajar yang telah dilaksanakan saja.

Fenomena-fenomena di atas tidak terlepas dari kinerja guru itu sendiri. Mengingat guru adalah panutan bagi siswa/i. Kinerja juga dapat disebabkan oleh berbagai faktor misalnya: komitmen, kepemimpinan, kompensasi, komunikasi, motivasi, promosi jabatan, kompetensi dan budaya organisasi. Budaya organisasi yang diterapkan diantaranya adalah aturan perilaku dimana dalam penggunaan bahasa umum yaitu Bahasa Indonesia yang baik dan benar terlaksana dengan baik dan norma yaitu standar perilaku guru pada saat proses belajar mengajar dilaksanakan dengan baik dan nilai dominan dalam mencapai standar mutu pendidikan pada kenyataannya terlaksana dengan baik. Filosofi dalam hal keharmonisan dalam organisasi juga terlihat terlaksana dengan baik dimana para guru 
memiliki hubungan yang baik tetapi dari segi aturan masih kurangnya para guru dalam menaatinya hal ini dapat dilihat dari keterlambatan para guru sedangkan iklim organisasi dapat dilihat dari hubungan antara para kepala sekolah dan guru terhadap orang tua murid maupun pihak lain terjadi dengan baik.

\section{Rumusan Masalah}

Berdasarkan uraian dari latar belakang di atas, maka rumusan masalah penelitian ini adalah: bagaimana pengaruh budaya organisasi terhadap kinerja guru pada perguruan Buddhist Manjusri Pematangsiantar.

\section{Tujuan Penelitian}

Adapun tujuan penelitian yang dilakukan adalah sebagai berikut: untuk mengetahui pengaruh budaya organisasi terhadap kinerja guru pada perguruan Buddhist Manjusri Pematangsiantar.

\section{Metode Penelitian}

Penulis menggunakan desain penelitian yaitu penelitian lapangan dan penelitian kepustakaan. Populasinya adalah guru Perguruan Buddhist Manjusri Pematangsiantar dengan jumlah 40 orang. Metode pengumpulan data adalah melalui wawancara, dokumentasi dan kuesioner yang bersumber dari data primer dan sekunder yang dianalisa dengan analisa deskriptif kualitatif dan analisa deskriptif kuantitatif.

\section{B. LANDASAN TEORI}

\section{Budaya Organsiasi}

Budaya berasal dari bahasa Sansekerta buddhayah sebagai bentuk jamak dari kata budhi yang artinya akal atau segala sesuatu yang berkaitan dengan akal pikiran, nilai-nilai dan sikap mental manusia. Ndraha (2003:128) mendefenisikan budaya sebagai asumsi-asumsi dan pola-pola makna yang mendasar, yang dianggap sudah selayaknya dianut dan dimanifestasikan oleh semua pihak berpartisipasi dalam organisasi. Menurut Hasibuan (2005:24) Organisasi adalah suatu sistem perserikatan formal, berstruktur dan terkoordinasi dari sekelompok orang yang bekerja sama dalam mencapai tujuan tertentu. Schein dalam Luthans (2006:124) menyatakan bahwa budaya organisasi adalah pola asumsi dasar diciptakan, ditemukan atau dikembangkan oleh kelompok tertentu saat mereka menyesuaikan diri dengan masalah-masalah eksternal dan integrasi internal yang telah bekerja cukup baik serta dianggap berharga dan karena itu diajarkan pada anggota baru sebagai cara yang benar untuk menyadari, berpikir dan merasakan hubungan dengan masalah tersebut.

Budaya memiliki beberapa fungsi di dalam suatu organisasi. Robbins (2002:283) mengemukakan beberapa fungsi budaya organisasi sebagai berikut: budaya menciptakan perbedaan antara satu organisasi dengan organisasi lain, budaya berfungsi untuk menyampaikan rasa identitas kepada anggota-anggotta organisasi, budaya mempermudah penerusan komitmen hingga mencapai batasan yang lebih luas, melebihi batasan ketertarikan inidividu, budaya mendorong stabilitas sistem sosial, budaya bertugas sebagai pembentuk rasa dan mekanisme pengendalian yang memberikan panduan dan bentuk prilaku serta sikap karyawan.

Menurut Ndraha (2010:76) pembentukan budaya diawali oleh para pendiri melalui tahapan sebagai berikut:

a. Seseorang mempunyai gagasan untuk mendirikan sebuah organisasi atau perusahaan berdasarkan VM (Virtual Machine) tertentu.

b. Ia menggali dan mengarahkan sumber-sumber, baik orang ini yang sepaham dan setujuan dengan dia (SDM), biaya, teknologi dan sebagainya.

c. Mereka meletakkan dasar organisasi berupa susunan organisasi dan tatakerja.

Sedangkan menurut Robbins (2008:267) proses penciptaan budaya terjadi dalam 3 cara yaitu:

a. Pendiri hanya merekut dan mempertahankan karyawan yang sepikiran dan seperasaan dengan mereka.

b. Mereka melakukan indoktrinasi dan menyosialisasikan cara pikir dan berprilaku mereka kepada karyawan.

c. Perilaku pendiri sendiri bertindak sebagai model peran yang mendorong karyawan untuk mengidentifikasi diri, menginternalisasi keyakinan, nilai dan asumsi pendiri tersebut.

Gordon dan Cummincs dalam Sopiah (2008:133) mengajukan 10 (sepuluh) karakteristik budaya organisasi yang meliputi dimensi struktual dan perilaku, yaitu:

a. Inisiatif individual: tingkat tanggung jawab, kebebasan dan independensi yang dimiliki individu.

b. Toleransi terhadap tindakan beresiko: sejauh mana para anggota dianjurkan untuk bertindak agresif, inovatif dan berani mengambil resiko.

c. Arah: sejauh mana organisasi tersebut menciptakan sasaran dan harapan mengenai prestasi dengan jelas

d. Integrasi: sejauh mana unit-unit dalam organisasi didorong untuk bekerja dengan cara terkoordinasi.

e. Dukungan dari manajemen: sejauh mana para manajer dapat berkomunikasi dengan jelas, memberi bantuan serta dukungan terhadap bawahan mereka.

f. Kontrol: sejumlah peraturan dan pengawasan langsung yang digunakan untuk mengawasi dan mengendalikan perilaku anggota.

g. Identitas: sejauh mana para anggota mengidentifikasi dirinya secara keseluruhan dengan organisasinya ketimbang dengan kelompok kerja tertentu atau dengan bidang keahlian profesional.

h. Sistem imbalan: sejauh mana alokasi imbalan (misalnya kenaikan gaji dan promosi) didasarkan atas kriteria prestasi pegawai sebagai kebalikan dari senioritas, sikap pilih kasih dan sebagainya. 
i. Toleransi terhadap konflik: sejauh mana para pegawai didorong untuk mengemukakan konflik dan kritik secara terbuka.

j. Pola-pola komunikasi: sejauh mana komunikasi organisasi dibatasi oleh hierarki kewenangan formal.

\section{Kinerja}

Menurut Hasibuan (2008:94), kinerja adalah suatu hasil kerja yang dicapai seseorang dalam melaksanakan tugas-tugas yang dibebankan kepadanya yang didasarkan atas kecakapan, pengalaman, dan kesungguhan serta waktu. Sedangkan menurut Cherington (2000:76) mengemukakan bahwa kinerja menunujukkan pencapaian target kerja yang berkaitan dengan kualitas, kuantitas dan waktu. Menurut Mathis dan Jackson (2006:378), kinerja (performance) pada dasarnya adalah apa yang dilakukan atau tidak dilakukan oleh karyawan. Kemudian menurut Mankunegara (2002:67) kinerja dapat didefenisikan sebagai hasil kerja secara kualitas dan kuantitas yang dicapai oleh seorang pegawai dalam melaksanakan tugasnya sesuai dengan tanggung jawab yang diberikan kepadanya.

Menurut Isjoni dalam Lie (2012:142) kinerja guru akan menjadi optimal, bilamana diintegrasikan dengan komponen persekolahan, apakah itu kepala sekolah, guru dan karyawan maupun anak didik. Kinerja guru akan bermakna bila diikuti dengan niat yang bersih dan ikhlas, serta selalu menyadari akan kekurangan yang ada pada dirinya, dan berupaya untuk meningkatkan atas kekurangan tersebut sebagai upaya untuk meningkatkan ke arah yang lebih baik dari kinerja hari kemarin, dan tentunya kinerja masa depan lebih baik dari kinerja hari ini. Kinerja guru sangat penting untuk diperhatikan dan dievaluasi karena guru mengemban tugas professional, artinya tugas-tugas hanya dapat dikerjakan dengan kompetensi khusus yang diperoleh melalui program pendidikan. Menurut Danim dalam Lie (2012:143) Guru memiliki tanggung jawab yang secara garis besar dapat dikelompokkan yaitu: guru sebagai pengajar, guru sebagai pembimbing, guru sebagai administrator kelas.

Menurut Departemen Pendidikan nasional PP No.19/2005, Permendiknas No.11/2011, Indikator penilaian terhadap kinerja guru dilakukan terhadap tiga kegiatan pembelajaran di kelas yaitu: perencanaan program kegiatan, pembelajaran, pelaksanaan kegiatan pembelajaran, evaluasi/penilaian pembelajaran.

Mulyasa dalam Lie (2012:155) menyatakan bahwa hubungan budaya organisasi sekolah dengan kinerja guru dapat dilihat dari perspektif Kebijakan Departemen Pendidikan Nasional, bahwa dalam kepemimpinannya kepala sekolah mempunyai sejumlah peran yang harus diperankan, yaitu sebagai edukator, sebagai manajer, sebagai administrator, sebagai supervisor, sebagai leader, sebagai pencipta iklim kerja dan sebagai wirausahaan. Salah satu peran yaitu pencipta iklim kerja. Menurut Sutrisno (2010:156) budaya yang tertanam kuat dan nilainilai budaya diterima dengan baik serta pegawai melaksanakan tugas yang seharusnya dilaksanakan dengan norma-norma yang telah ditetapkan akan menunjukkan sejauh mana pegawai dapat menyelesaikan tugasnya dengan cepat, tepat dan benar sesuai dengan standar yang telah ditentukan.

\section{PEMBAHASAN}

\section{Analisa Deskripsi Kualitatif}

Analisis deskriptif digunakan untuk memperoleh gambaran atau deskripsi mengenai tanggapan dari guru. Adapun penetapan kriteria nilai rata-rata jawaban dari responden tersebut dimasukkan ke dalam kelas-kelas interval dimana penentuan intervalnya memakai rumus sebagai berikut:

Interval Kelas $=\underline{\text { Nilai Tertinggi }- \text { Nilai Terendah }}$ Jumlah Kelas

Kriteria:

Nilai tertinggi $=5$

Nilai terendah $=1$

Jumlah kelas $=5$

Dari rumus di atas diperoleh interval kelas = 0,8 , sehingga berlaku ketentuan kategori dengan hasil sebagai berikut:

Tabel 2

Nilai Interval dan Kategori Jawaban Responden.

\begin{tabular}{|c|c|}
\hline $\begin{array}{c}\text { Nilai } \\
\text { Interval }\end{array}$ & Kategori \\
\hline $1,00-1,80$ & $\begin{array}{c}\text { Sangat Tidak Baik/Sangat } \\
\text { Rendah }\end{array}$ \\
\hline $1,81-2,60$ & Tidak Baik/Rendah \\
\hline $2,61-3,40$ & Kurang Baik/Cukup Tinggi \\
\hline $3,41-4,20$ & Baik/Tinggi \\
\hline $4,21-5,00$ & Sangat Baik/sangat Tinggi \\
\hline
\end{tabular}

Sumber: Hasil Pengolahan Data.

\section{a) Gambaran Budaya Organisasi}

Salah satu fungsi budaya organisasi yang diterapkan dalam Perguruan Buddhist Manjusri adalah sebagai pola perilaku. Dimana budaya organisasi berfungsi untuk membantu membentuk perilaku-perilaku para guru dalam melaksanakan proses kegiatan belajar mengajar. Mengingat guru adalah panutan bagi siswa/i nya. Maka perilaku guru harus disiplin. Salah satunya adalah dalam hal penggunaan bahasa dan ketepatan waktu dalam proses masuk kelas untuk melaksanakan kegiatan belajar mengajar.

Secara keseluruhan sisi budaya organisasi memiliki nilai rata-rata 4,04 yang dinilai baik. Hal tersebut berarti berdasarkan hasil kuesioner, guru Perguruan Buddhist Manjusri Pematangsiantar telah menunjukkan budaya organisasi yang baik. Hal tersebut hendaknya ditingkatkan agar budaya 
organisasi pada masa-masa yang akan datang bisa lebih baik lagi.

\section{b) Gambaran Kinerja Guru}

Kinerja atau performance pada dasarnya merupakan prestasi kerja, pelaksanaan kerja, pencapaian kerja atau hasil kerja/unjuk kerja dalam suatu organisasi. Ukuran kinerja guru terlihat dari rasa tanggung jawabnya menjalankan amanah, profesi yang diembannya dan rasa tanggungjawab moral di pundaknya. Semua ini akan terlihat kepada kepatuhan dan loyalitasnya di dalam menjalankan tugas keguruannya di dalam kelas dan tugas kependidikannya di luar kelas.

Sikap ini akan dibarengi juga dengan rasa tanggungjawabnya mempersiapkan segala perlengkapan pengajaran sebelum melaksanakan proses pembelajaran. Salah satu penilaian kinerja yang diterapkan dalam Perguruan Buddhist Manjusri adalah perbaikan kinerja. Dimana setiap bulannya dilakukan evaluasi kinerja misalnya dalam hal melaksanakan tugasnya apakah sudah diselesaikan tepat waktu.

Secara keseluruhan sisi kinerja memiliki nilai rata-rata 3,98 yang dinilai baik. Hal tersebut berarti berdasarkan hasil kuesioner, guru Perguruan Buddhist Manjusri Pematangsiantar telah menunjukkan kinerja yang baik. Hal tersebut hendaknya ditingkatkan agar kinerja pada masamasa yang akan datang akan semakin baik lagi.

\section{Analisa Deskriptif Kuantitatif \\ a. Regresi Linier Sederhana}

Analisa data dalam penelitian ini menggunakan analisa regresi sederhana. Analisa regresi linear sederhana digunakan untuk mengetahui pengaruh variabel bebas $(X)$ dan variabel terikat $(\mathrm{Y})$, dimana $\mathrm{X}$ adalah Budaya Organisasi dan Y adalah Kinerja Guru. Untuk melihat pengaruh variabel dengan persamaan regresi tersebut maka dilakukan perhitungan secara manual untuk memperoleh nilai a dan $\mathrm{b}$ dengan notasi sebagai berikut: $=\mathrm{a}+\mathrm{bX}$.

Hasil dari koefisien regresi yang didapat adalah sebagai berikut: $=14,35+0,595 \mathrm{X}$. Persamaan tersebut menjelaskan bahwa terdapat pengaruh yang positif antara Budaya Organisasi (X) terhadap Kinerja Guru (Y) pada Perguruan Buddhist Manjusri Pematangsiantar. Semakin baik budaya organisasi maka semakin baik juga kinerja guru. Sebaliknya, apabila budaya organisasi rendah maka kinerja guru juga akan rendah.

\section{b. Korelasi dan Koefisien Determinasi}

Untuk menghitung kekuatan hubungan budaya organisasi terhadap kinerja guru, dilakukan melalui analisis korelasi. Dari besarnya nilai perhitungan korelasi 0,5726 menunjukkan bahwa hubungan variabel yang sedang antara budaya organisasi dan kinerja guru yang diteliti di Perguruan Buddhist Manjusri Pematangsiantar.
Sedangkan untuk mengukur seberapa besar variabel dependen (bebas) menjelaskan variabel indenpenden (terikat), digunakan koefisien determinasi (Kd). Nilai variabel Y (kinerja guru) sebesar 32,78 \% baik rendahnya kinerja guru dijelaskan oleh variabel X (budaya organisasi). Sedangkan $67,22 \%$ dijelaskan oleh faktor-faktor lain yang tidak dibahas pada penelitian ini seperti: komitmen, kepemimpinan, kompensasi, komunikasi, motivasi, promosi jabatan dan kompetensi.

\section{c. Uji Hipotesis (uji t)}

Untuk menarik kesimjugan yang valid, maka harus dilakukan uji hipotesis. Dari hasil perhitungan koefisien korelasi diketahui bahwa budaya organisasi berhubungan terhadap kinerja guru. Untuk menguji kebenarannya, dilakukan uji hipotesis. Dari hasil uji t di atas, diketahui bahwa nilai $\mathrm{t}$ hitung $(4,305)>\mathrm{t}$ tabel $(2,024)$ sehingga $\mathrm{Ho}$ ditolak. Hasil tersebut menunjukkan bahwa budaya organisasi berpengaruh positif terhadap kinerja guru pada Perguruan Buddhist Manjusri Pematangsiantar.

\section{Evaluasi}

\section{a. Budaya Organisasi}

Dalam hal meningkatkan budaya organisasi tenaga pendidiknya sehingga tenaga pendidiknya lebih meningkatkan mutu kinerjanya. Perlunya peningkatan pelatihan-pelatihan dan pemberian motivasi terhadap semua tenaga pendidik dan peserta didik. Pentingnya membuat peraturanperaturan yang lebih mengikat untuk meningkatkan disiplin dan dapat membina kesantunan di lingkungan sekolah menjadi lebih baik. Harus membuat Standar Operation Prosedur (SOP) untuk pencapaian efektivitas dan efisiensi yang lebih baik lagi. Ketika hal-hal di atas dilakukan dengan baik, tenaga pendidik akan merasa puas dengan sekolah. Rasa puas tersebut akan meningkatkan budaya organisasi dalam diri tenaga pendidik dan peserta didik sehingga mereka lebih meningkatkan perilaku, keberaturan dan efektivitas serta efesiensi. Lebih penting lagi, kinerja guru dan tanggung jawab atas pekerjaan mereka dapat terlaksana dengan baik.

\section{b. Kinerja Karyawan}

Untuk meningkatkan kinerja guru, maka perlu diperhatikan: Kemampuan menggunakan in focus, laptop dan internet perlu ditingkatkan serta perlu diberi pelatihan terhadap para guru untuk menggunakan media-media pembelajaran tersebut guna meningkatkan kemampuan guru terhadap media pembelajaran, Perlunya menggunakan alatalat praktek maupun penelitian tindakan kelas. Dengan demikian strategi pembelajaran yang digunakan dapat diperbaiki dan bukan hanya dengan menggunakan buku paket, Perlu ditingkatkan lagi penegakkan disiplin siswa dengan cara memberi sanksi terhadap setiap pelanggaran disiplin, Kemampuan dalam menentukan cara-cara dan alatalat evaluasi untuk meningkatkan kinerja guru dapat dilakukan dengan mengadakan workshop maupun 
pelatihan-pelatihan yang dapat meningkatkan kemampuan. Guru sebagai sumber daya manusia merupakan aset yang penting bagi sekolah. Kunci untuk memajukan sekolah berada pada guru. Untuk meningkatkan kinerja, salah satu langkah yang dapat dilakukan sekolah adalah meningkatkan budaya organisasi guru. Semakin baik budaya organisasi yang ada pada guru, semakin baik juga kontribusi yang dapat diberikan guru terhadap sekolah dalam pencapaian tujuannya.

\section{KESIMPULAN DAN SARAN}

\section{Kesimpulan}

a. Berdasarkan hasil penelitian, budaya organisasi yang ada pada Perguruan Buddhist Manjusri Pematangsiantar dinilai Baik dengan nilai ratarata 4,04. Kinerja dengan nilai rata-rata 3,98.

b. Budaya organisasi berpengaruh terhadap kinerja guru, hal ini dapat dilihat dari hasil pengujian regresi yang menunjukkan tanda positif pada persamaan sebagai berikut: $\hat{\mathrm{Y}}=14,95+$ $0,595 \mathrm{X}$.

c. Dengan nilai $r=0,5726$ terdapat hubungan yang sedang antara variabel $\mathrm{X}$ dan variabel Y. Kinerja guru melalui uji koefisien determinasi (R) sebesar 32,78\% dapat dijelaskan oleh budaya organisasi dan sisanya sebesar 67,22 \% dapat dijelaskan faktor lain yang tidak dibahas dalam penelitian ini.

d. Dari hasil pengujian $t_{\text {hit }}=4,305$ sedangkan $t_{\text {tab }}$ pada tingkat kepercayaan adalah sebesar 2,024. Oleh karena itu $t_{\text {hit }}>t_{\text {tab }}$, berarti variabel budaya organisasi berpengaruh terhadap kinerja guru, sehingga Ho ditolak dan Ha diterima, artinya budaya organisasi berpengaruh positif terhadap kinerja guru Perguruan Buddhist Manjusri Pematangsiantar.

\section{Saran}

a. Agar standar perilaku guru dan pelaksanaannya, standar perilaku siswa dan pelaksanaannya, keberaturan dalam pembinaan kesantunan di lingkungan sekolah dan standar pencapaian efektivitas dan efisiensi pencapaiannya dapat ditingkatkan maka perlu dilakukan peningkatan pelatihan-pelatihan dan pemberian motivasi terhadap semua tenaga pendidik dan peserta didik agar standar perilaku guru dan siswa dapat ditingkatkan serta membuat peraturan-peraturan yang lebih mengikat untuk meningkatkan disiplin dan dapat membina kesantunan di lingkungan sekolah menjadi lebih baik dan membuat Standar Operation Prosedur (SOP) untuk pencapaian efektivitas dan efisiensi.

b. Agar kinerja guru dalam penggunaan media pembelajaran, kinerja guru dalam penggunaan strategi pembelajaran, kinerja guru dalam penegakan disiplin siswa dan kinerja guru dalam kemampuan menentukan cara-cara dan alat-alat evaluasi pencapaiannya dapat ditingkatkan maka penyediaan sarana dan prasarana yang menunjang aktivitas belajar mengajar.
Mengingat perkembangan zaman semakin modern dan canggih maka dunia pendidikan juga dituntut agar bisa memberikan pendidikan yang lebih baik lagi. Dalam hal ini kemampuan menggunakan in focus, laptop dan internet perlu ditingkatkan serta perlu diberi pelatihan terhadap para guru untuk menggunakan media-media pembelajaran tersebut guna meningkatkan kemampuan guru terhadap media pembelajaran. Untuk meningkatkan strategi pembelajaran, perlu dilakukan cara seperti menggunakan alat-alat praktek maupun penelitian tindakan kelas. Dengan demikian strategi pembelajaran yang digunakan dapat diperbaiki dan bukan hanya dengan menggunakan buku paket. Dalam hal penegakkan disiplin siswa perlu ditingkatkan lagi dengan cara memberi sanksi terhadap setiap pelanggaran disiplin. Untuk meningkatkan kinerja guru dalam kemampuan menentukan cara-cara dan alat-alat evaluasi dapat dilakukan dengan mengadakan workshop maupun pelatihan-pelatihan yang dapat meningkatkan kemampuan para guru.

c. Sehubungan dengan keterbatasan-keterbatasan yang ada pada penulis, penelitian ini masih terdapat kelemahan-kelemahan dan belum dapat mengungkap seluruh variabel yang dapat mempengaruhi kinerja guru pada Perguruan Buddhist Manjusri Pematangsiantar. Sebagai bahan masukan untuk penelitian selanjutnya, perlu memperbanyak variabel penelitian, seperti komitmen, kepemimpinan, kompensasi, komunikasi, motivasi, promosi jabatan dan kompetensi.

\section{E. DAFTAR PUSTAKA}

Cherington. 2000. The Management of Human Resource. New Jersey : Prentice Hall International,Inc,.

Dessler, Gary. 2004. Manajemen Sumber Daya Manusia. Jakarta: Prenhallindo. 2006. Manajemen Sumber Daya Manusia Edisi Kesepuluh Jilid I. Jakarta: PT. Indeks

Hasibuan, Malayu S.P. 2005. Manajemen Sumber Daya Manusia. Cetakan Ketujuh. Edisi Revisi. Jakarta: Penerbit Bumi Aksara. 2008. Organisasi dan Motivasi. Jakarta: Penerbit Bumi Aksara.

Lie, Darwin. 2012. Analisis Pengaruh Kepemimpinan Kepala Sekolah, Budaya Organisasi Sekolah, Kompetensi Guru Terhadap Motivasi Dan Komitmen Guru Serta Implikasinya Terhadap Kinerja Guru (Studi Kasus Pada SMA di Lima Kabupaten - Kota Provinsi Sumatera Utara), Bandung: Universitas Pasundan. Disertasi.

Luthans, Fred. 2006. Perilaku Organisasi. Edisi Sepuluh. Jakarta: Penerbit Andi. 
Mangkunegara, A.A Anwar Prabu. 2002. Manajemen SDM Perusahaan. Jakarta : Penerbit Bumi Aksara.

Mangkuprawira, Sjafri TB. 2004. Manajemen Sumber Daya Manusia Strategik. Jakarta: Gahlia Indonesia.

Mathis, Robert L. dan John H. Jackson. 2006. Manajemen Sumber Daya Manusia. Jakarta: Penerbit Salemba Empat.

Mondy, R. Wayne. 2008. Manajemen Sumber Daya Manusia Jilid I Edisi 10. Jakarta: Penerbit Erlangga.

2008. Manajemen Sumber Daya Manusia. Jakarta: Penerbit Erlangga.

Ndraha, Taliziduhu. 2003. Teori Budaya Organisasi. Cetakan Kedua. Jakarta: PT. Rineka Cipta. 2010. Budaya Organisasi. Cetakan Ketiga. Jakarta: PT. Rineka Cipta.

Permendiknas No. 11/2011 tentang Sertifikasi Guru.

PP No. 19/2005 tentang Standar Nasional Pendidikan.

Robbins, Stephen P. 2002. Prinsip-Prinsip Perilaku Organisasi. Edisi Kelima. Jakarta: Penerbit Erlangga.
2006. Perilaku Organisasi. Edisi Indonesia. Edisi Kesepuluh. Jakarta: PT. Prenhallindo. 2008. Perilaku Organisasi. Buku Kedua. Jakarta: Penerbit Salemba.

Simamora, Hendry. 2004. Manajemen Sumber Daya Manusia. Jakarta: Penerbit Erlangga.

Simbolon, Hotman. 2009. Statistika. Yogyakarta: Graha Ilmu.

Sopiah. 2008. Perilaku Organisasi. Yogyakarta: Penerbit Andi.

Sudewa,

Wira.

2012. http://www.slideshare.net/wirasudewa90/co ntoh-proposalskripsi: tahun akses 2013.

Sugiyono. 2008. Metode Penelitian Kuantitatif Kualitatif dan R\&D. Bandung: Penerbit Alfabeta.

Sutrisno, Edy. 2010. Budaya Organisasi. Jakarta: Kencana Prenada Media Group.

Sutrisno, Edy. 2010. Budaya Organisasi. Cetakan Pertama. Jakarta: Kencana Prenada Media Group.

UU No.14/2005 tentang Guru dan Dosen Pasal 9 tentang Kualifikasi Akademik. 